\title{
Effect of operating parameters on coal gasification
}

\author{
Akanksha Mishra $^{1}\left[\right.$ : Shalini Gautam ${ }^{2} \cdot$ Tripurari Sharma $^{2}$
}

Received: 18 June 2017/Revised: 22 November 2017/Accepted: 27 January 2018/Published online: 7 March 2018

(C) The Author(s) 2018. This article is an open access publication

\begin{abstract}
Coal combustion and gasification are the processes to utilize coal for production of electricity and many other applications. Global energy demand is increasing day by day. Coal is an abundant source of energy but not a reliable source as it results into high $\mathrm{CO}_{2}$ emissions. Energy industries are expected to decrease the $\mathrm{CO}_{2}$ emission to prevent global warming. Coal gasification is a process that reduces the $\mathrm{CO}_{2}$ emission and emerges as a clean coal technology. Coal gasification process is regulated by several operating parameters. A Number of investigations have been carried out in this direction. A critical review of the work done by several researchers in the field of coal gasification has been compiled in this paper. The effect of several operating parameters such as coal rank, temperature, pressure, porosity, reaction time and catalyst on gasification has been presented here.
\end{abstract}

Keywords Coal gasification - Temperature and pressure $\cdot$ Porosity $\cdot$ Rank

\section{Introduction}

The drastic rise in the world population and continuous increasing energy demand due to improvement in living standards has led to a rise in demand of energy worldwide. Among the various energy resources in the world, coal is the most abundant and cheapest but its use results into high carbon dioxide emission. Awareness of public towards increasing environmental pollution and impact of $\mathrm{CO}_{2}$ and other gas emissions on climate change has led to the utilization of clean coal technology. Clean coal technology

Akanksha Mishra

6akanksha2@gmail.com

Shalini Gautam

shalini_ism@rediffmail.com

Tripurari Sharma

hodfmeism@yahoo.co.in

1 Department of Mechanical Engineering, Sharda University, Greater Noida, India

2 Department of Fuel and Mineral Engineering, Indian Institute of Technology (Indian School of Mines), Dhanbad, India along with carbon capture and sequestration is competent to emerge as zero emission technology. Carbon capture and storage (CCS) has been identifies as a key technology for moderate global climate change (Rubin et al. 2015). The comparatively high cost of the current CCS system is major hurdle in its extensive development at power plants and other industrial services (IPCC 2014). In order to develop better lower cost technologies, worldwide efforts are in progress (NCC 2015). Now a day's coal gasification has emerged as a clean and effective way to convert solid coal to gaseous fuels which in turn are used to produce power or heat.

Coal gasification is defined as a reaction of solid coal with limited amount of oxygen, air, steam, carbon dioxide or the mixture of these gases at or above $700{ }^{\circ} \mathrm{C}$, which yields gaseous products used as source of energy. The gasification of coal consists of two consecutive steps: pyrolysis of coal and gasification of char obtained from coal pyrolysis. There are several types of coal gasifiers such as moving bed, fluidized bed and entrained flow gasifiers where complete gasification reactions take place. Among the two steps of coal gasification the rate of second step i.e., gasification of 
char is much slower than that of the first, so the construction and design of coal gasifier is dependent on the gasification of char. Pyrolysis of coal in gasification process is mainly dependent on the organic properties of the coal and it is important because it has influence on the subsequent conversion process. Gasification offers several advantages over conventional combustion such as reduction of carbon dioxide in the environment and for a given amount of fuel; the volume of the gas obtained from gasification is less compared to that obtained from the combustion. The lesser gas volume needs smaller equipment which in turn lowers overall cost (Basu 2006). The drawback of the gasification is that carbon conversion efficiency is not $100 \%$, useful part of the fuel remains as char in the gasifier (Basu 2006). Gasification characteristics of coal are significantly dependent on the type of coal and operating conditions. Integrated gasification combined cycle (IGCC) has been developed to be an eco friendly power generation system via coal. IGCC is highly efficient in reducing $\mathrm{CO}_{2}$ emissions. In many counties such as USA coal gasification power plants are used commercially and experts are predicting that coal gasification will be the best for power generation sector in future. IGCC plants produce syngas (mainly hydrogen and carbon monoxide) which is cleaned from $\mathrm{H}_{2}, \mathrm{NH}_{3}$ and Particulate Matter. Clean syngas is burnt in a combustion turbine as a fuel. Electrical generator is driven by a combustion turbine (CT). Exhaust heat coming out from CT is recovered and used to boil water which creates steam for a steam turbine generator. IGCC is termed as combine cycle because of the use of two turbines simultaneously i.e., combination of combustion turbine and steam turbine. Combination of two turbines is one of the reason by which IGCC based power generation becomes efficient. Higher power generation efficiency means less amount of fuel is used to generate the rated power which will result in better economics and reduced formation of green house gases (Kristiansen 1996). Big companies, such as Siemens, Shell, and ConocoPhillips have put up IGCC facilities around the world (Hoffmann and Szklo 2011). Mahinpey and Gomez (2016) reported that the IGCC plants are designed with $\mathrm{CO}_{2}$ and sulfur capture in order to take away the majority of such harmful constituents from the product gas. Mahinpey and Gomez (2016) explained one of the possible gasification routes of power generation from different feedstock. They reported chemical synthesis is also possible with syngas by using of the Fischer-Tropsch (FT) (Fig. 1).

The objective of this paper is to provide an overview of gasification process and to review the findings of several researchers in this area, so that comprehensive information on coal gasification will be available for new researchers and energy sector people. The observations reported by different authors in terms of different variable parameters like catalytic load, porosity, volatile matter, reaction time and effect of pressure on yield products have been reviewed critically under the following headings.

\subsection{Coal quality}

Coalification is a transformation of vegetable matter to form peat, lignite, Semi bituminous, bituminous, semi-anthracite and anthracite. The degree of coalification is termed as rank of coal. Reactivity of the coal is related to its rank. Rank of the coal is a most important variable in the nature of the coals. It is determined by carbon content of the coal, volatile matter and calorific value. Coal is composed of hydroaromatic and aromatic building blocks. The building blocks are connected to each other via variable cross-links. The level of porosity in the coals has been decided by the extent of cross-links between the building blocks. There are three types of structures present in the wide range of coal which is suggested by Hirsch (1954):

(1) Open structure: This type of structure is found in low rank coal (carbon content is up to about 85\%). These types of coals are generally highly porous because lamellae are connected by significant number of cross links and these cross-links are randomly oriented.

(2) Liquid structure: This type of structure is found in bituminous coal (carbon content is from about 85\%-91\%). These types of coals are less porous because with increase in coal rank cross-links start to disappear and lamellae show some specific orientation.

(3) Anthracite structure: This type of structure is typically found in high rank coal (carbon content is above $91 \%$ ). As the rank of the coal increases, the cross links disappear completely and the degree of orientation of lamellae increases greatly with respect to each other.

Pore structure of the coal has significant role in coal combustion and gasification. International Union of Pure \& Applied Chemistry classified the pores into three categories: Microporse (diameter $<2 \mathrm{~nm}$ ), Mesopores (diameter 2- $50 \mathrm{~nm}$ ) and Macropores (diameter > $50 \mathrm{~nm}$ ) (Saha 2013). Several models have been proposed in order to explain the gas-solid reaction on porous char during combustion and gasification, like: random pore model, isolated pore model, lattice model and pore tree model. Several researches such as Simons (1983) and Bhatia and Gupta (1994) studied several models in detail. Porosity of the coal is usually calculated from the particle density $\left(D_{\mathrm{p}}\right)$ and true $\left(H_{\mathrm{t}}\right)$ density:

Porosity $(\%)=\frac{\left(H_{t}-D_{p}\right)}{H_{t}} \times 100$

\subsection{Coal gasification}

Coal gasification is carried out in limited amount of oxygen i.e., one-fifth to one-third of the theoretically oxygen 


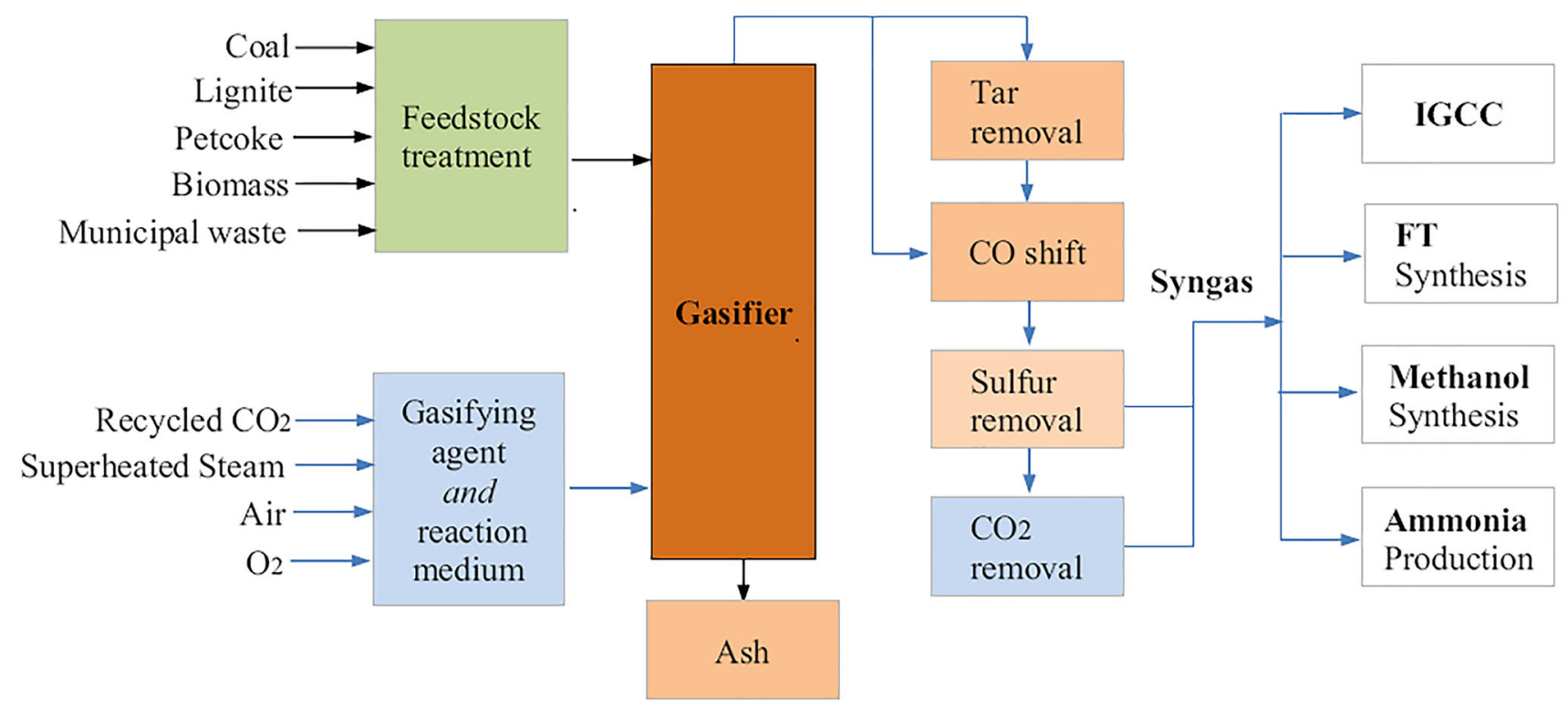

Fig. 1 Possible plant configuration for different applications of gasification, Mahinpey and Gomez (2016)

required for complete combustion. Hydrogen and carbon monoxide are the main products of gasification, only a fraction of carbon is combusted for generation of heat. In gasifiers the following two physicochemical processes take place (Basu 2006):

(1) Pyrolysis or devolatilization As coal enters into a gasifier, it is first dried by the hot gases present in the gasifier. A series of complex physical and chemical process start slowly at temperature $<350{ }^{\circ} \mathrm{C}$ and accelerate as temperature exceeds $700{ }^{\circ} \mathrm{C}$. The composition of the release products of pyrolysis is depending upon the temperature, pressure and gas composition during pyrolysis. The pyrolysis process can be represented by the following reaction:

Coal $\rightarrow$ Heat $\rightarrow$ Char $\rightarrow$ Gases $\rightarrow$ Vapors or liquid

Following three products are produced by pyrolysis:

(1) Light gases like: $\mathrm{CO}, \mathrm{CO}_{2}, \mathrm{H}_{2}, \mathrm{H}_{2} \mathrm{O}, \mathrm{CH}_{4}$.

(2) Tar which is a corrosive and viscous liquid composed of heavy inorganic and organic molecules.

(3) Char which is a solid residue mainly contains carbon.

Gasification Gasification process involves a series of endothermic reactions which are supported by the heat produced from the following combustion reactions occurred inside a gasifier:

$\mathrm{C}+\mathrm{O}_{2} \leftrightarrow \mathrm{CO}_{2} \quad \Delta H=-393.5 \mathrm{~kJ} / \mathrm{mol}$

$\mathrm{H}_{2}+1 / 2 \mathrm{O}_{2} \leftrightarrow \mathrm{H}_{2} \mathrm{O} \quad \Delta H=-285.9 \mathrm{~kJ} / \mathrm{mol}$

The major gasification reactions are (Rodrigues-Reinoso 1991; Saha 2013):
(2) Water gas shift reaction The partial oxidation of carbon by steam occurred in this reaction.

$\mathrm{C}+\mathrm{H}_{2} \mathrm{O} \leftrightarrow \mathrm{H}_{2}+\mathrm{CO} \quad \Delta H=118.5 \mathrm{~kJ} / \mathrm{mol}$

(3) Boudouard reaction The char present in the gasifier reacts with the carbon dioxide and produces $\mathrm{CO}$ :

$\mathrm{CO}_{2}+\mathrm{C} \leftrightarrow 2 \mathrm{CO} \quad \Delta H=159.0 \mathrm{~kJ} / \mathrm{mol}$

(4) Shift conversion This endothermic reaction is known as water-gas shift reaction which results in increasing ratio of hydrogen to carbon monoxide in the gas. This reaction is employed in production of synthesis gas.

$\mathrm{CO}+\mathrm{H}_{2} \mathrm{O} \leftrightarrow \mathrm{CO}_{2}+\mathrm{H}_{2} \quad \Delta H=-42.3 \mathrm{~kJ} / \mathrm{mol}$

(5) Methanation Nickel based catalysts at $1100{ }^{\circ} \mathrm{C}$ and 6-8 bar pressure accelerate this reaction. Formation of methane is preferred in IGCC applications because of its high heating value.

$\mathrm{C}+2 \mathrm{H}_{2}=\mathrm{CH}_{4} \quad \Delta H=-74.5 \mathrm{KJ} / \mathrm{mol}$

Figure 2 represents above mentioned exothermic and endothermic reactions in updraft gasifier. It is difficult to predict the exact composition of the gases obtained from gasifier because it depends upon number of parameters such as: temperature, operating pressure, gasifying medium, fuel composition, moisture content etc.

\subsection{Types of gasifiers}

The complete gasification reactions carried out in the gasifiers which need to be operate at certain temperature in 


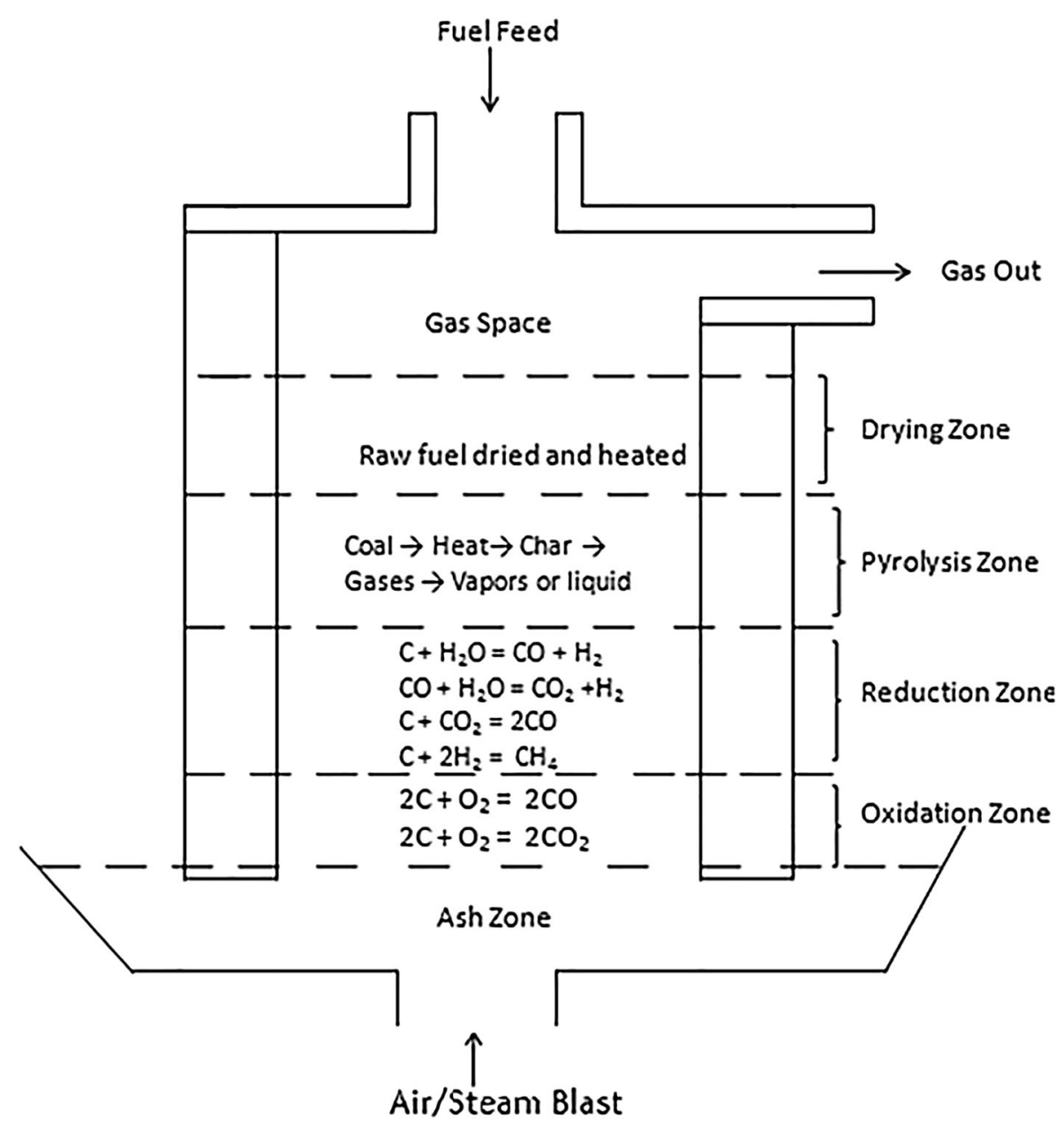

Fig. 2 Exothermic and endothermic reactions in updraft gasifier

order to drive certain endothermic carbon-steam and carbon-carbon dioxide reactions, the required temperature is maintained by heat evolved from exothermic reaction between oxygen and fuel.

Depending upon the medium of gasification, gasifiers can be classified into two categories (Basu 2006):

(1) Air Blown: Air is used as a gasification medium in this type of gasifiers.

(2) Oxygen-Blown: Pure oxygen is used as a gasification medium.

When air is used as gasification medium, the $\mathrm{N}_{2}$ is simultaneously brought into the process which results in the product gas dilution. As a result product gas will have a lower calorific value i.e., $3-6 \mathrm{MJ} / \mathrm{m}^{3}$ compared to that of oxygen blown $\left(10-12 \mathrm{MJ} / \mathrm{m}^{3}\right)$ which is free from diluents like $\mathrm{N}_{2}$.

Depending upon the contact between gas and fuel, gasifiers can be further divided into following three types:

(1) Moving or Fixed Bed Gasifier.
(2) Fluidized bed Gasifier.

(3) Entrained Bed Gasifier.

(1) Moving bed gasifier: Moving Bed Gasification is an oldest technology which is extensively used in commercial practices. Moving bed gasifier is also known as fixed bed gasifier. Gasification medium is slowly flow through a fixed bed of solid particles. Up-draft and down draft are the two possible configurations of this type of gasifiers, depending upon the direction of flow of gasification medium. The up-draft configuration is more commonly used because there is low tar content. The preferred feed coal size is $5-80 \mathrm{~mm}$. The combustion zone attains a maximum temperatures of the order of $1500-1800$ and $1300{ }^{\circ} \mathrm{C}$ for the slagging and dry ash gasification, respectively. Temperature profile is formed over the bed, so that the feed coal is successively preheated, dried, pyrolyzed, gasified and combusted. Lurgi gasifier is the oldest moving bed gasifier technology which is commercially proven. The major disadvantage offered by moving bed gasifier is processing of highly caking coal without pre-treatment (Saha 2013). 
(2) Fluidized bed gasifier: In fluidized bed gasifiers the bed of solid particles behaves as a fluid. In this type of gasifier feedstock of particle size less than $5 \mathrm{~mm}$ is suspended in the oxygen rich gas. The rising gas reacts with the feedstock and maintained the fluidized state of the coal particles. A uniform temperature distribution is obtained in this type of gasifiers. Fluidized bed gasifiers avoid clinker formation and defluidization of the bed because they are operated in the temperature range of $800-1050{ }^{\circ} \mathrm{C}$ which is well below the ash fusion temperature. Ash discharge conditions may differ in fluidized bed gasifiers, either dry or agglomerated ash. Dry ash fluidized bed gasifier has traditionally operated on low rank of coal; whereas agglomerated ash fluidized bed gasifiers are suitable for any rank of coal.

(3) Entrained flow gasifier: Pulverized coal particles of size less than $0.1 \mathrm{~mm}$ are suspended in a stream of steam and oxygen at high speed. Depending upon the method of coal feeding, dry (Nitrogen as a transport gas used) or wet (carried in water slurry), gasifiers are accepting almost any type of coal. Entrained flow gasifiers ensures high carbon conversion because they operate at a high temperature of $1400-1600{ }^{\circ} \mathrm{C}$ (well above the ash slagging temperature). Entrained flow gasifiers are high capacity gasifiers because the gas residence time is measured in seconds. Commercial entrained bed gasifiers for a large scale of applications are Texo, Koppers-Totzek and Shell. Entrained bed gasifiers are available for the much larger capacities such as greater than $100 \mathrm{MWe}$ than other two types of gasifiers.

The thermal efficiency and output of the gasification process are greatly subjective to the magnitude and location of heat transfer in the gasifiers. A proper understanding of the heat transfer mechanism in a gas solid interface inside a gasifier is critical. So the modes of heat transfer in the gasifiers are the important aspect of the study. The modes of heat transfer may be considered as: heat transfer between the gas and particles, between the bed and walls of bed furnace, from the bed to immersed tube surfaces, to the tubes of boiler immersed in the heat exchanger and to the wall of cyclone.

\subsection{Gas cleaning}

The product of gasification contains desirable components like $\mathrm{CO}, \mathrm{H}_{2}, \mathrm{CH}_{4}$ and undesirable components like ash, entrained soot, tar, certain amount of $\mathrm{H}_{2} \mathrm{~S}$ and traces of $\mathrm{NH}_{3}, \mathrm{COS}, \mathrm{HCl}$ and $\mathrm{HCN}$ (Basu 2006). The undesirable components need to be removed from product gas. There are number of techniques used to remove undesirable compounds, some of which are discussed here: Limestone can be fed into the fluidized bed gasifiers along with coal to capture most of the $\mathrm{H}_{2} \mathrm{~S}$. An external desulfurization system is used to remove any residual $\mathrm{H}_{2} \mathrm{~S}$. Chemical and physical methods are used to remove the tar from the product gas. Tar is destroyed and converted into smaller molecules in chemical method and tar yielding is removed by physical method. Cyclones are used to remove particulate matter. In order to remove particulate matter at high temperature, number of technique are developed which includes granular bed filters, ceramic barrier filter, high temperature fabric filters etc.

\section{Effect of operating parameters}

\subsection{Effect of catalytic activity on coal gasification}

Catalytic gasification of coal is extensively studied for the development of efficient and economic gasification processes. Several researchers (Agarwal and Sears 1980; Radovic et al. 1983; Takarada et al. 1986; Miura et al. 1989; Ochoa et al. 2001; Song and Kim 1993; Li 2007; Hattingh et al. 2011) investigated the effect of catalyst on reactivity of char obtained from coals ranging peat to anthracite during gasification in the presence of varying gasifying mediums. Presence of catalyst in char can be inherent or may be impregnated. From the investigation of several researchers (Agarwal and Sears 1980; Radovic et al. 1983; Takarada et al. 1986; Miura et al. 1989; Song and Kim 1993; Ochoa et al. 2001; Li 2007; Hattingh et al. 2011), it can be said that the reactivity of char having inherent or impregnated catalyst is dependent upon a number of factors such as weight and type of catalyst. Song and Kim (1993) investigated the effect of presence of catalyst by weight percentage on char reactivity. They reported that under the $3 \%$ catalyst addition with same operating conditions, pure salt catalytic activity is in the order of $\mathrm{K}_{2} \mathrm{CO}_{3}>\mathrm{Na}_{2} \mathrm{CO}_{3}>\mathrm{FeSO}_{4}>\mathrm{K}_{2} \mathrm{SO}_{4}>$ $\mathrm{Fe}\left(\mathrm{NO}_{3}\right)_{3}$ during steam gasification of bituminous coal char. They have also reported that the reactivity increases with the addition of catalyst up to $6 \mathrm{wt} \%$.

Hattingh et al. (2011) reported that increased amount of $\mathrm{CaO}$ and $\mathrm{MgO}$ content enhances catalytic effect of coal which in turn enhances reactivity of coal. Schobert (1992) reported that the presence of $\mathrm{Na}_{2} \mathrm{O}$ and $\mathrm{K}_{2} \mathrm{O}$ also increases the reactivity but their effect is not considered due to negligible amount of such species in ash.

Hence, it may be concluded that all the catalyst either present or added to coal, affects the gasification behavior of coal by changing the reactivity of coal.

\subsection{Effect of porosity of char on coal gasification}

Pyrolysis results in removal of volatile matters and yields a solid residue called char (Kiihl et al. 1992). It is important to study the internal structure of solid residue after heat 
treatment because it affects the char reactivity. There are number of randomly oriented and different shapes pores with radii ranging from one length of nanometers to tens of nanometer (Liu et al. 2000). To explain the formation of pores during gasification, there are three mechanisms (Rodrigues-Reinoso 1991): (1) the width of existing pores, (2) the formation of new pores by selective gasification of certain structural components and (3) the opening of formerly unreachable pores. The total pore volume measured is further divided into two groups i.e., micropore region and the combined mesopore and macropore region (Siauw et al. 1984 and Rodrigues-Reinoso 1991). The micropores play important role in the reactivity of char particles because micro-pores take up approximately $95 \%$ of total surface area, while the meso-pores and macro-pores provide the passage to reactant gases to reach the active carbon sites in the micro-pores where actual gasification reaction take place (Siauw et al. 1984; Liu et al. 2000). At low carbon conversion, pore swelling is dominant which result in an increased surface area, as reaction proceeds pores starts collapsing which leads to decrease in surface (Liu et al. 2000). Kiihl et al. (1992) reported that steam gasification produces a less microporous structure than $\mathrm{CO}_{2}$ gasification. Feng and Bhatia (2003) reported that in air gasification pore structure development is different from $\mathrm{CO}_{2}$ gasification. During $\mathrm{CO}_{2}$ gasification, volume and surface area of small micropores increases very dramatically as gasification reaction progresses whereas in air gasification volume and surface area of small micropores does not change appreciably with carbon conversion after a particular extent of carbon conversion (Feng and Bhatia 2003)

So the gasifying agents also play an important role in finding effect of porosity on coal reactivity.

Siauw et al. (1984) have reported that the total pore volume and micropore volume decreases with increase in carbon content or rank of coal because the lower rank coal are much more porous than higher rank coal. The microporous volume of sample coal decreases linearly with increase in the coal rank (Siauw et al. 1984). Most of the pores of lignite lie in the range of micro and meso-pores (Siauw et al. 1984). The reactivity of coal with change in rank can be justified by the explanation of (Jenkins et al. 1973) i.e., higher rank coal has less feeder pores and lower reactive sites on the surface compared to lignite, which reduces the reactivity of higher rank coal. Siauw et al. (1984) have also investigated that the coal reactivity is almost constant up to certain total pore volume and then sudden rise in reactivity observed with increase in total pore volume. This sudden rise in reactivity can be understood by opening of unreachable pores and formation of new pores as reaction proceeds. Jenkins et al. (1973) reported that the reactivity of char having large proportion of feeder pores is high, because the reactivity of reactant gas to diffuse into the internal surface of micropores is enhanced.

Effect of temperature on pores formation has also been investigated by Jenkins et al. (1973). They explained that as the temperature increases up to a certain level (i.e., $600{ }^{\circ} \mathrm{C}$ ) porosity increases and concentration of feeder coal decreases but results in lower reactivity, with further increase in temperature. The reactivity of coal after certain temperature can be decreased because of heat treatment which promotes closing of pores. Closing of pores caused due to presence of large molecules, compressing disorganized carbon, cross linking and collapsing of pores at higher temperature due to plasticity of char (Feng and Bhatia 2003). But in contrast to above discussion, Feng and Bhatia (2003) also reported that with the increase in heat treatment time and temperature, volume of closed pores increases and there is no change in size of various pores with carbon conversion because shrinkage occurs maintaining the same distance between crystalline structures. In contrast to above results, Miura et al. (1989) and Hurt et al. (1991) have reported that the pore structure is not a factor which controls the gasification reaction rate of highly reactive char.

\subsection{Effect of volatile matter on coal gasification}

Jenkins et al. (1973), Beamish et al. (1998), Messenbock et al. (2000), Zhang et al. (2006) and Kim et al. (2011) have reported that the reactivity of coal char during gasification is dependent on volatile matter content in coal and rank of coal. Reactivity of char is directly proportional to the volatile content of coal, i.e., reactivity of char increases with increase in volatile matter content (Beamish et al. 1998; Zhang et al. 2006; Kim et al. 2011). Messenbock et al. (2000) reported the variation of volatile content of coal with respect to change in pressure. Tread of Messenbock et al. (2000) showed that there is a decrease in total volatile content with increasing pressure during pyrolysis, this trend is observed because of deposition of secondary char on the particles and suppression of volatile yield at higher temperature.

\subsection{Effect of reaction time/residence time on coal gasification}

Shufen and Ruizheng (1994), Ye et al. (1998), Harris et al. (2006) and Wu et al. (2009) have investigated the effect of reaction time on carbon conversion during gasification. Ye et al. (1998) investigated that fixed carbon conversion during $\mathrm{CO}_{2}$ and $\mathrm{H}_{2} \mathrm{O}$ gasification is a function of reaction time and gasification temperature (Fig. 3). Ye et al. (1998) reported that the rate of fixed carbon conversion increases 


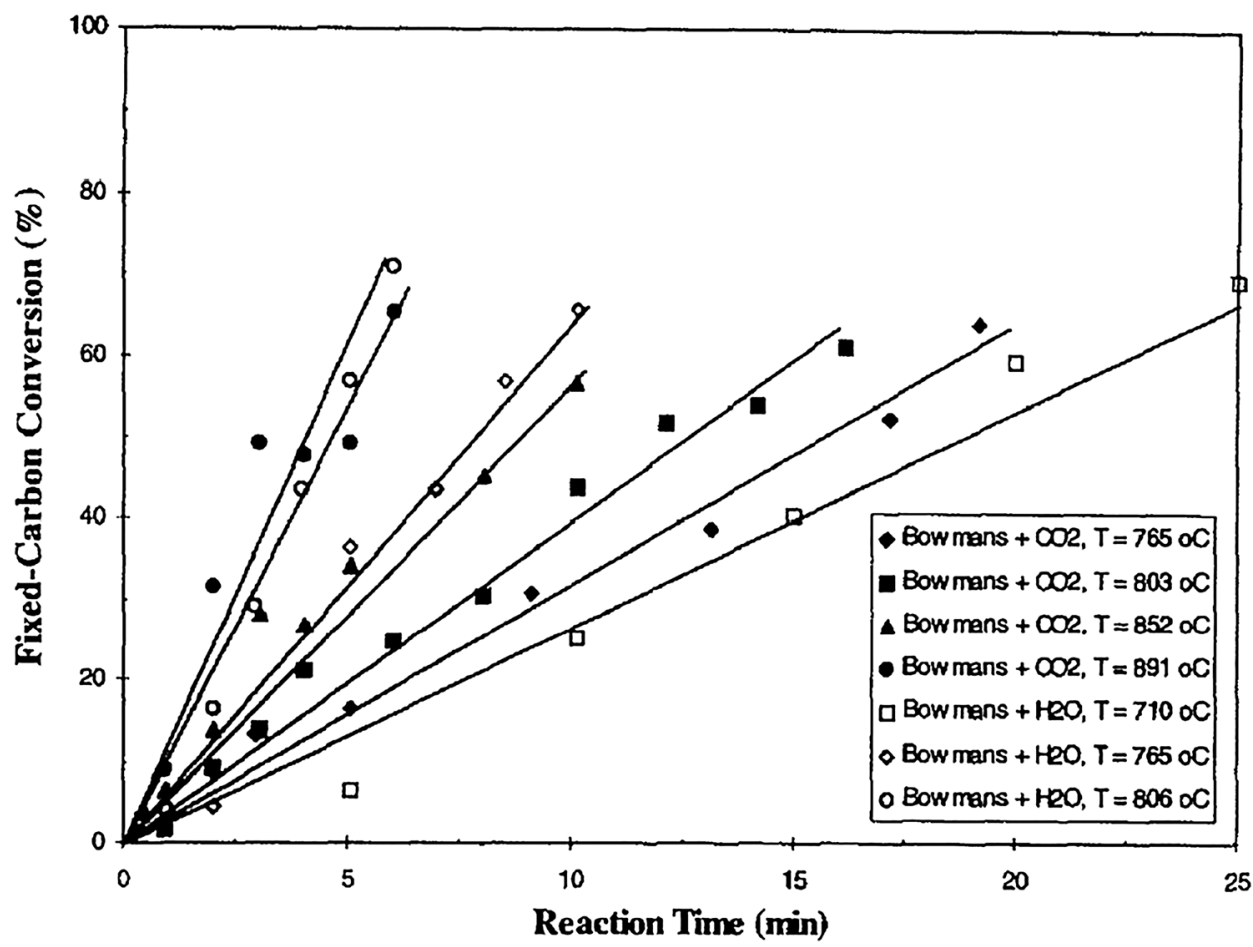

Fig. 3 Fixed-carbon conversion versus reaction time for $\mathrm{CO}_{2}$ and $\mathrm{H}_{2} \mathrm{O}$ gasification of Bowmans coal at different temperatures (particle size 1.6-2.4 mm), Ye et al. (1998)

with increasing gasification temperature at a particular reaction time for both $\mathrm{CO}_{2}$ and steam gasification. Ye et al. (1998) also mentioned that the fixed carbon conversion increases with increasing reaction time at a particular gasification temperature.

Results of Ye et al. (1998) are in good agreement with other researchers (Shufen and Ruizheng 1994; Harris et al. 2006; Wu et al. 2009).

So from the above discussed results, it may be concluded that for the same reaction time with increase in temperature carbon conversion increases and also with the increase in reaction time carbon conversion increases irrespective of different pyrolysis and gasification atmosphere.

\subsection{Effect of temperature on coal gasification}

Temperature plays an important role in gasification of coal. Higher gasification temperature increases the carbon conversion which improves gasification rate.

Kim et al. (2011) have reported the effect of temperature ranging from 1050 to $1350{ }^{\circ} \mathrm{C}$ on carbon conversion during gasification. They found that as the gasification temperature increases gasification time required for carbon conversion decreases. According to them nearly half gasification time is required for complete carbon

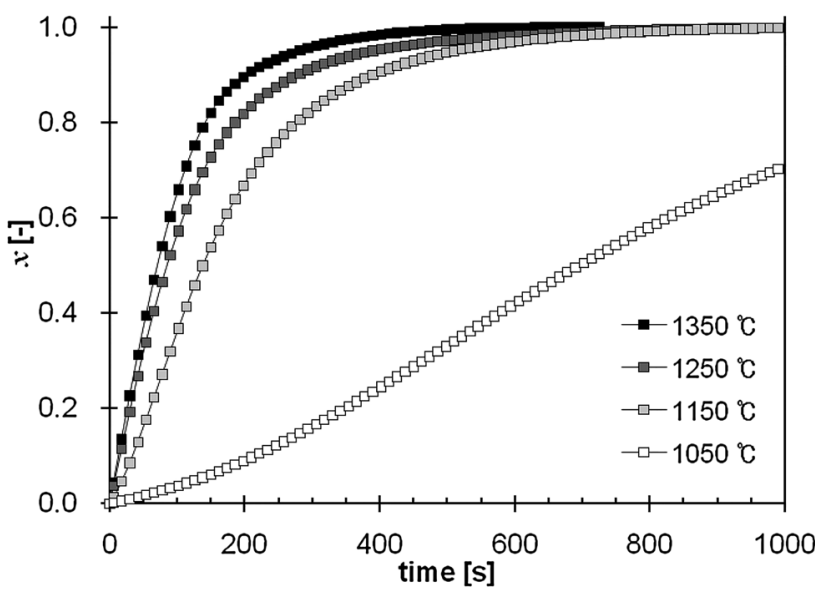

Fig. 4 Carbon conversion verses time curve, Kim et al. (2011)

conversion at $1350{ }^{\circ} \mathrm{C}$ than that of $1050{ }^{\circ} \mathrm{C}$ (Fig. 4). Liu et al. (2008) have studied the effect of temperature on gasification rate of char namely SC, RC and RDC prepared from Chines Binxian coal. The gasification rate of SC char decreased with increase in carbon conversion during gasification reaction and gasification rate increased with increase in temperature. The gasification rate of char SC and $\mathrm{RC}$ was similar (Fig. 5a, b). At $1300{ }^{\circ} \mathrm{C}$ the profile of 

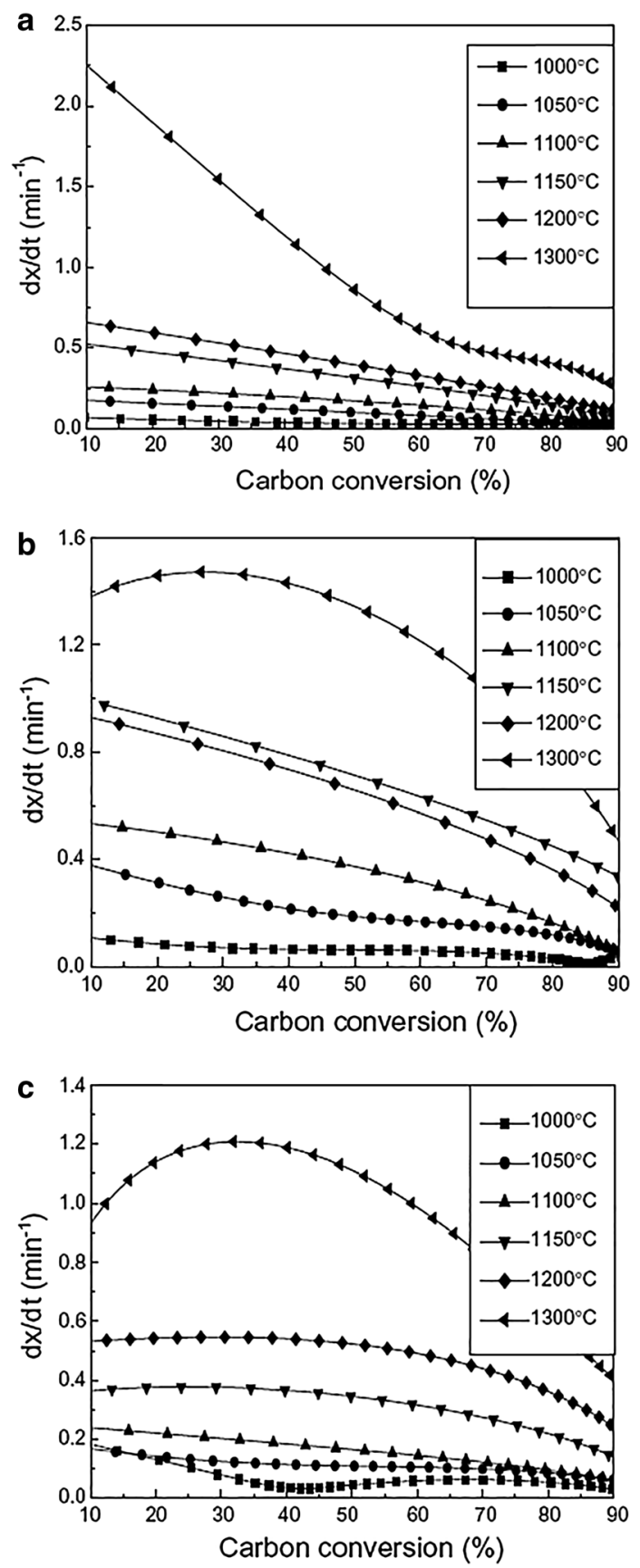

Fig. 5 Effect of temperature on gasification rate of char a SC, b RC, c RDC, Liu et al. (2008)

$\mathrm{RC}$ showed highest gasification rate at $27 \%$ carbon conversion. Similarly for RDC coal char gasification rate showed parabolic profile at 1150,1200 and $1300{ }^{\circ} \mathrm{C}$ for the carbon conversion 24\%, 31\%, 32\% respectively (Fig. 5c). According to them the variation in gasification rate was due to structural variation of char which was due to difference in material concentration and char preparation method.
According to Xiao et al. (2006) the gasification temperature plays an important role in char gasification. As the bed temperature increases, the carbon conversion during gasification reaction increases by oxidation, Boudouard and water gas shift reaction which shows almost linear relationship. Results of Xiao et al. (2006) are in good agreement with the other authors (Liu et al. 2008; Kim et al. 2011). Corella et al. (2006) have reported that gasification temperature has both the positive effect as well as negative effect on coal gasification reaction. For the high carbon conversion, enhanced gasification rate, high throughput and low tar content in product gases, high gasification temperature $\left(850-900{ }^{\circ} \mathrm{C}\right)$ is required. But apart from this while operating gasifier at atmospheric pressure it is taken into consideration that above $750{ }^{\circ} \mathrm{C}$ product gases always contain less than $20 \%$ by volume $\mathrm{CO}_{2}$, therefore there is no $\mathrm{CO}_{2}$ capture. To capture $\mathrm{CO}_{2}$ with $\mathrm{CaO}$ at atmospheric pressure it is required to operate gasifier at below $750{ }^{\circ} \mathrm{C}$ which in turn exceeds the tar content in product gases beyond a limit. Such gasification is called dirty gas and it has no further use in any field. Hence they concluded that there is a confliction for the optimum gasification temperature.

Several researchers (Alvarez et al. 1994; Ahn et al. 2001; Zhang et al. 2006; Cakal et al. 2007; Liu et al. 2008; Everson et al. 2008; Fouga et al. 2011; Tanner and Bhattacharya 2016; Wang et al. 2015) have studied kinetic behavior of coal gasification using different kinetic models. They have used different raw materials and various operating conditions. They have reported the values of activation energy which has been compiled in Table 1. In this table the material used by various researchers, gasification medium, kinetic model and the values of activation energy has been compiled.

\subsection{Effect of pressure on yield products during coal gasification}

Sha et al. (1990), Roberts et al. (2003), Canel et al. (2005) and Yu et al. (2007) have investigated the effect of pressure on yield products during pyrolysis and gasification. Sha et al. (1990) and Roberts et al. (2003) have reported that the pyrolysis pressure of coal affects the morphology of the produced char. It is also reported that with the increase in pyrolysis pressure tendency of char to become sponge is increased due to opening of large void areas and accessible porosity (Roberts et al. 2003). Sha et al. (1990) reported that the char reactivity is decreased when it is produced by high pressure pyrolysis. Sha et al. (1990) investigated the effect of operating pressure on coal gasification. They have reported that there is increase in yield of $\mathrm{CH}_{4}$ and $\mathrm{C}_{2} \mathrm{H}_{6}$ irrespective of pyrolysis medium $\left(\mathrm{H}_{2}\right.$ or $\left.\mathrm{N}_{2}\right)$ with increase in operating pressure but as compared to $\mathrm{N}_{2}$ pyrolysis 
Table 1 Kinetic models and activation energy

\begin{tabular}{|c|c|c|c|c|c|}
\hline $\begin{array}{l}\text { S. } \\
\text { No. }\end{array}$ & References & Material & $\begin{array}{l}\text { Gasification } \\
\text { medium }\end{array}$ & Kinetic model & $\begin{array}{l}\text { Activation energy } \\
(\mathrm{kJ} / \mathrm{mol})\end{array}$ \\
\hline 1. & $\begin{array}{l}\text { Alvarez et al. } \\
\text { (1994) }\end{array}$ & Bituminous coals & $\mathrm{O}_{2}$ & $\begin{array}{l}K(X)=\frac{1}{f(p)}\left(\frac{\mathrm{d} X}{\mathrm{~d}_{t}}\right) \\
X: \text { Carbon conversion, } f(p) \text { : Dependence of reaction } \\
\quad \text { rate on oxygen, } p \text { : Partial pressure }\end{array}$ & $105-130$ \\
\hline 2. & $\begin{array}{l}\text { Ahn et al. } \\
\text { (2001) }\end{array}$ & $\begin{array}{l}\text { Indonesia Sub } \\
\text { Bituminous Coal }\end{array}$ & $\mathrm{CO}_{2}$ & $\begin{array}{l}\text { Non reactive core model: } \\
\frac{\mathrm{d} X}{\mathrm{~d} t}=k P_{c o 2}^{n}(1-X)^{2 / 3} \\
k: \text { Apparent reaction coefficient, } n \text { : Apparent reaction } \\
\text { order, } X: \text { Carbon conversion, } t \text { : Reaction time, } P_{\mathrm{CO} 2} \text { : } \\
\mathrm{CO}_{2} \text { Gas concentration }\end{array}$ & 71.5 \\
\hline 3. & $\begin{array}{l}\text { Ahn et al. } \\
\text { (2001) }\end{array}$ & $\begin{array}{l}\text { Indonesia Sub } \\
\text { Bituminous Coal }\end{array}$ & $\mathrm{CO}_{2}$ & $\begin{array}{l}\text { Modified model: } \\
R=k P_{\text {gas }}^{n} P_{\text {Total }}^{m}(1-X)^{2 / 3} \\
\frac{\mathrm{d} X}{\mathrm{~d} t} A e^{-(E / R T)} P_{C O 2}^{n} P_{\text {Total }}^{m}(1-X)^{2 / 3} \\
A \text { : Pre-exponential factor, } E \text { : Apparent activation } \\
\quad \text { energy, } R \text { : Gas constant, } T \text { : Gasification temperature }\end{array}$ & 71.5 \\
\hline 4. & $\begin{array}{c}\text { Zhang et al. } \\
\text { (2006) }\end{array}$ & $\begin{array}{l}6 \text { Chinese } \\
\text { Anthracite chars }\end{array}$ & $\mathrm{CO}_{2}$ and Steam & $\begin{array}{l}\text { Shrinking core model: } \\
\begin{array}{l}\frac{\mathrm{d} x}{\mathrm{~d} t}==k(1-x)^{2 / 3} \text { or } 1-(1-x)^{1 / 3}=-k t \\
\text { Homogeneous model: } \\
\frac{d x}{d t}=k(1-x) \text { or } \ln (1-x)=-k t \\
K=k_{\mathrm{o}} \mathrm{e}^{-E \mathrm{a} / R T} \\
x \text { : Carbon conversion, } t \text { : Reaction time, } k: \text { Reaction rate, } \\
\quad k_{\mathrm{o}}: \text { Pre-exponential factors, Ea: Activation energies, } \\
R \text { : Gas constant, } T: \text { Gasification temperature }\end{array}\end{array}$ & $\begin{array}{l}213-250 \text { for steam } \\
\text { and } 146-202 \text { for } \\
\mathrm{CO}_{2} \text { gasification }\end{array}$ \\
\hline 5. & $\begin{array}{l}\text { Cakal et al. } \\
\text { (2007) }\end{array}$ & $\begin{array}{l}\text { Turkey coal Soma, } \\
\text { Seyitomer, } \\
\text { Elbistan, } \\
\text { Tuncbilek }\end{array}$ & $\mathrm{CO}_{2}$ & $\begin{array}{l}R=-\frac{1}{W 0}\left(\frac{\mathrm{d} W}{\mathrm{~d} t}\right) \\
R: \text { Reactivity, Wo: Initial weight of the coal (for } \\
\text { pyrolysis period) or char (for gasification period), } \\
\mathrm{d} W / \mathrm{d} t: \text { Instantaneous weight loss rate. }\end{array}$ & $29.0-124.8$ \\
\hline 6. & Liu et al. (2008) & Binxian Coal & $\mathrm{CO}_{2}$ & $\begin{array}{l}\frac{\mathrm{d} x}{\mathrm{~d} t}=A \exp \left(-\frac{E}{R T}\right)(1-x)^{n} \\
x: \text { Carbon conversion, } t: \text { Gasification time, } T: \\
\quad \text { Gasification temperature, } A: \text { Frequency factor }\left(\mathrm{s}^{-1}\right) \text {, } \\
E: \text { activation energy }(\mathrm{kJ} / \mathrm{mol}) \text { and } R: \text { gas constant } \\
(8.314 \mathrm{~J} /(\mathrm{mpl} \mathrm{k})) \text {. }\end{array}$ & $160-180$ \\
\hline 7. & $\begin{array}{l}\text { Everson et al. } \\
\text { (2008) }\end{array}$ & Inertinite-rich coal & $\begin{array}{l}\mathrm{CO}_{2}-\mathrm{N}_{2} \\
\text { mixtures }\end{array}$ & $\begin{array}{l}\frac{\mathrm{d} X}{\mathrm{~d} t}=\frac{r_{\mathrm{s}}(1-X) S_{\mathrm{o}} \sqrt{1-\varphi \ln (1-X)}}{\left(1-\varepsilon_{\mathrm{o}}\right)} \\
X: \text { Fractional conversion of carbon (ash free), } t \text { : time }(\mathrm{s} \\
\quad \text { and min }), r_{\mathrm{S}} \text { reaction rate }(\mathrm{m} / \mathrm{s}), S_{\mathrm{o}}: \text { initial surface } \\
\text { area }\left(\mathrm{m}^{2} \mathrm{~m}^{-3}\right), \varepsilon \text { initial porosity, } \varphi \text { : structural } \\
\text { parameter, Lo total pore length per unit volume } \\
\quad\left(\mathrm{mm}^{-3}\right), \\
\varphi=\frac{4 \pi L_{o}\left(1-\epsilon_{o}\right)}{S_{o}^{2}}\end{array}$ & $235( \pm 37)$ \\
\hline 8. & $\begin{array}{l}\text { Fouga et al. } \\
\text { (2011) }\end{array}$ & Argentinean coal & $\begin{array}{l}\mathrm{CO}_{2} 99 \% \text { purity } \\
\text { (AGA, } \\
\text { Argentina) } \\
\text { and } \mathrm{Ar} \\
99.99 \% \text { purity }\end{array}$ & $\begin{array}{l}\text { Isoconversional method: } \\
\text { Rate }=\frac{\mathrm{d} \alpha}{\mathrm{d} t}=G(\alpha) \cdot K(T) \cdot F\left(P_{C O 2}\right) \\
\text { Global rate equation: } \\
\frac{\mathrm{d} \alpha}{\mathrm{d} t}=(1-\alpha)^{2 / 3} \cdot K_{\mathrm{O}} \cdot B \cdot \exp \left(-\frac{E}{R T}\right) \cdot P_{\mathrm{co} 2}^{x} \\
A \text { : conversion degree, } t \text { : Time, } K(T) \text { : Arrhenius } \\
\quad \text { equation, } F\left(P_{\mathrm{CO} 2}\right) \text { : Dependence of the reaction rate } \\
\text { on the partial pressure of carbon dioxide, }\left(K_{\mathrm{o}} . . B\right) \text { : } \\
\text { Determined by the intersection of the curve of the } \\
\text { linear fit from the plot: -ln } t_{i} \text { versus } \ln \left(P_{\mathrm{CO} 2}(\mathrm{~g})\right), E \mathrm{E} \text { : } \\
\text { Activation energy. } X: \text { reaction order }\end{array}$ & $\begin{array}{l}185 \pm 5 \\
178 \pm 5\end{array}$ \\
\hline
\end{tabular}


Table 1 continued

\begin{tabular}{|c|c|c|c|c|c|}
\hline $\begin{array}{l}\text { S. } \\
\text { No. }\end{array}$ & References & Material & $\begin{array}{l}\text { Gasification } \\
\text { medium }\end{array}$ & Kinetic model & $\begin{array}{l}\text { Activation energy } \\
(\mathrm{kJ} / \mathrm{mol})\end{array}$ \\
\hline 9. & $\begin{array}{l}\text { Tanner and } \\
\text { Bhattacharya } \\
\text { (2016) }\end{array}$ & $\begin{array}{l}\text { Victorian brown } \\
\text { coal }\end{array}$ & $\begin{array}{c}\mathrm{CO}_{2} \text { and steam } \\
\text { gasification }\end{array}$ & $\begin{array}{l}\text { Volumetric model: } \\
\frac{\mathrm{d} X}{d t}=K_{V M}(1-X) \\
\text { Grain Model: } \\
\frac{\mathrm{d} X}{\mathrm{~d} t}=K_{G M}(1-X)^{2 / 3} \\
\text { Random pore model: } \\
\frac{\mathrm{d} X}{\mathrm{~d} t}=K_{R P M} \sqrt{[1-\varphi \ln (1-X)]} \\
\varphi=\frac{4 \pi L_{o}\left(1-\epsilon_{o}\right)}{S_{o}^{2}} \\
X: \text { char conversion } \\
k_{\mathrm{GM}}: \text { grain model reaction rate } \\
k_{\mathrm{RPM}}: \text { random pore model reaction rate } \\
\mathrm{k}_{\mathrm{VM}}: \text { volumetric model reaction rate } \\
\varphi: \text { dimensionless structural correlation for the random } \\
\text { pore model, } L \mathrm{o} \text { initial length of all particle pores per } \\
\text { unit volume, } S_{\mathrm{o}}: \text { initial char surface area per unit } \\
\text { volume }\end{array}$ & $\begin{array}{l}162-175 \\
\text { and } 119-165 \text { for } \\
\text { CO2 and steam, } \\
\text { respectively }\end{array}$ \\
\hline 10 & $\begin{array}{c}\text { Wang et al. } \\
\text { (2015) }\end{array}$ & $\begin{array}{l}\text { Biomass and } \\
\text { anthracite char }\end{array}$ & & $\begin{array}{l}\text { Random pore model: } \\
\frac{\mathrm{d} X}{\mathrm{~d} t}=K_{R P M} e^{-E a / R T}(1-X) \sqrt{[1-\varphi \ln (1-X)]} \\
\varphi=\frac{4 \pi L_{o}\left(1-\epsilon_{o}\right)}{S_{o}^{2}} \\
S_{\mathrm{o}}, L_{\mathrm{o}} \text { and } \varepsilon_{\mathrm{o}} \text { are the pore surface area, pore length, and } \\
\text { solid porosity, respectively } \\
\text { Volumetric model: } \\
\frac{\mathrm{d} X}{\mathrm{~d} t}=K_{V M} e^{-E a / R T}(1-X) \\
\text { Unreached core model: } \\
\frac{\mathrm{d} X}{\mathrm{~d} t}=K U C R M e^{-E a / R T}(1-X)^{2 / 3}\end{array}$ & 236.4-284.9 \\
\hline
\end{tabular}

medium percentage of yield products is higher in $\mathrm{H}_{2}$ atmosphere. From the Fig. $6 \mathrm{a}, \mathrm{b}$ it can be seen that there is slight increase in yield of $\mathrm{CH}_{4}$ and $\mathrm{C}_{2} \mathrm{H}_{6}$ with increase in pressure during $\mathrm{N}_{2}$ pyrolysis atmosphere which could be because of secondary cracking of tar where as there is higher increase in yield of $\mathrm{CH}_{4}$ and $\mathrm{C}_{2} \mathrm{H}_{6}$ with increase in pressure during $\mathrm{H}_{2}$ pyrolysis atmosphere which is due to rapid hydro-gasification of coal char and hydrogenation of gaseous hydrocarbons. They also reported that irrespective of pyrolysis atmosphere there is decrease in yield of $\mathrm{C}_{2} \mathrm{H}_{2}$ with increase in pressure where as the decrease in yield of $\mathrm{C}_{2} \mathrm{H}_{2}$ during $\mathrm{N}_{2}$ atmosphere is less as compared to $\mathrm{H}_{2}$ atmosphere because of hydro generation of unsaturated hydrocarbons.

Results of Sha et al. (1990) are in good agreement with the results of Canel et al. (2005) and Yu et al. (2007) with respect to increase in yield of $\mathrm{CH}_{4}$ as pressure increases but
Canel et al. (2005) have reported that there is a decreases in methane yield between 5 and $10 \mathrm{MPa}$. Results of Sha et al. (1990) for the increase in yield in $\mathrm{C}_{2} \mathrm{H}_{6}$ with pressure are similar with Canel et al. (2005).

Messenbock et al. (2000) reported the effect of pressure (1-30 bar) on total volatile yield during pyrolysis in the atmosphere. Figure 7 represented that there is a decrease in total volatile yield as pyrolysis pressure increases which is because of deposition of secondary char over particles and volatile release inhibition at higher pressure, this fall in total volatile yield is also been measured by other researcher (Yu et al. 2007).

Yu et al. (2007) have reported the decrease in tar yield and increased gas generation. The results of $\mathrm{Yu}$ et al. (2007) are contradicted by the results of Canel et al. (2005). Canel et al. (2005) reported that with increase in pressure tar yield increases (Fig. 8) and char yields decreases. They 

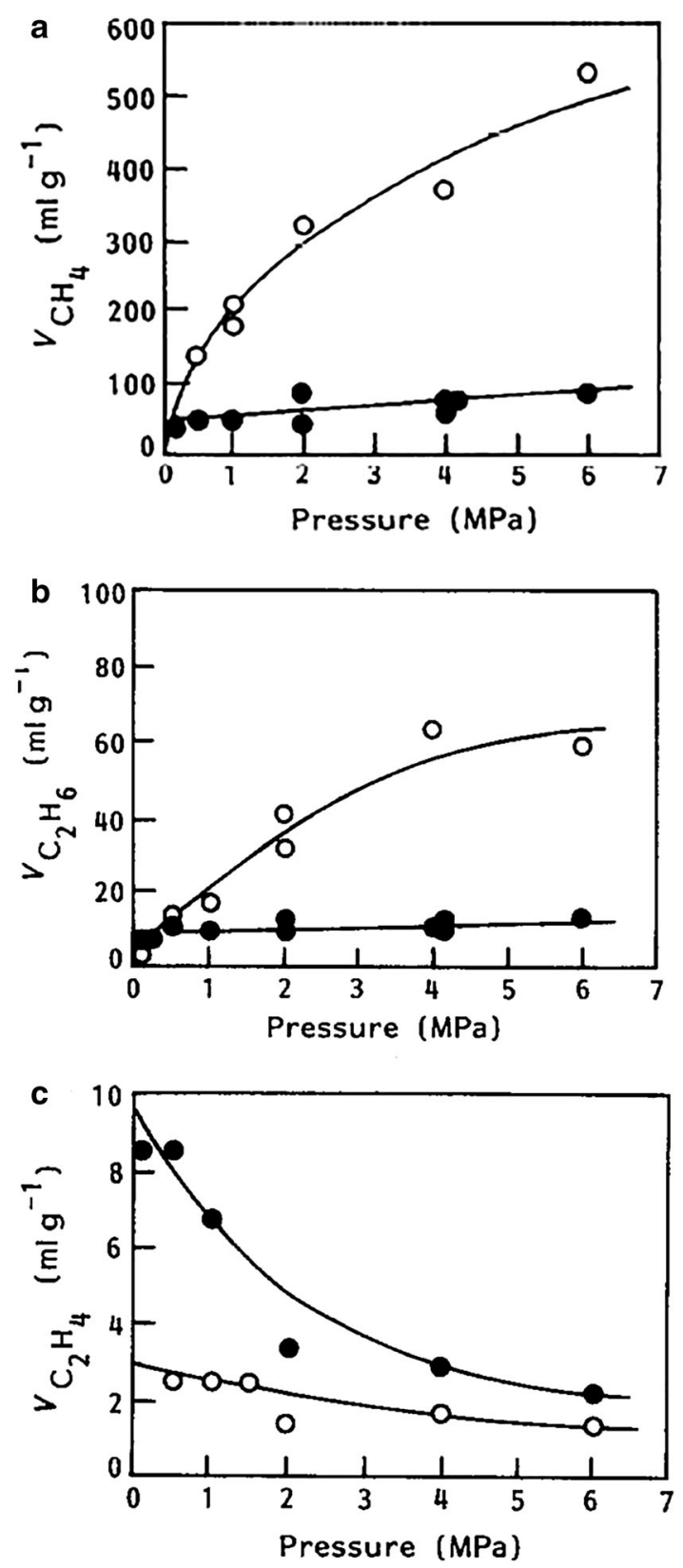

Fig. 6 Effects of pressure on: a $\mathrm{CH}_{4}$ yield at $800{ }^{\circ} \mathrm{C}, \mathbf{b} \mathrm{C}_{2} \mathrm{H}_{6}$ yield at $800{ }^{\circ} \mathrm{C}$, c $\mathrm{C}_{2} \mathrm{H}_{4}$ yield at $800{ }^{\circ} \mathrm{C}$ (Symbol: Open circle for $\mathrm{H}_{2}$ atmosphere and Filled circle for $\mathrm{N}_{2}$ atmosphere); Sha et al. (1990)

also reported that yield of gases increases with pressure and then started decreasing (Fig. 8).

Thus, it may be concluded that the effect of pyrolysis pressure on the gasification reactivity of char is not systematically proven.

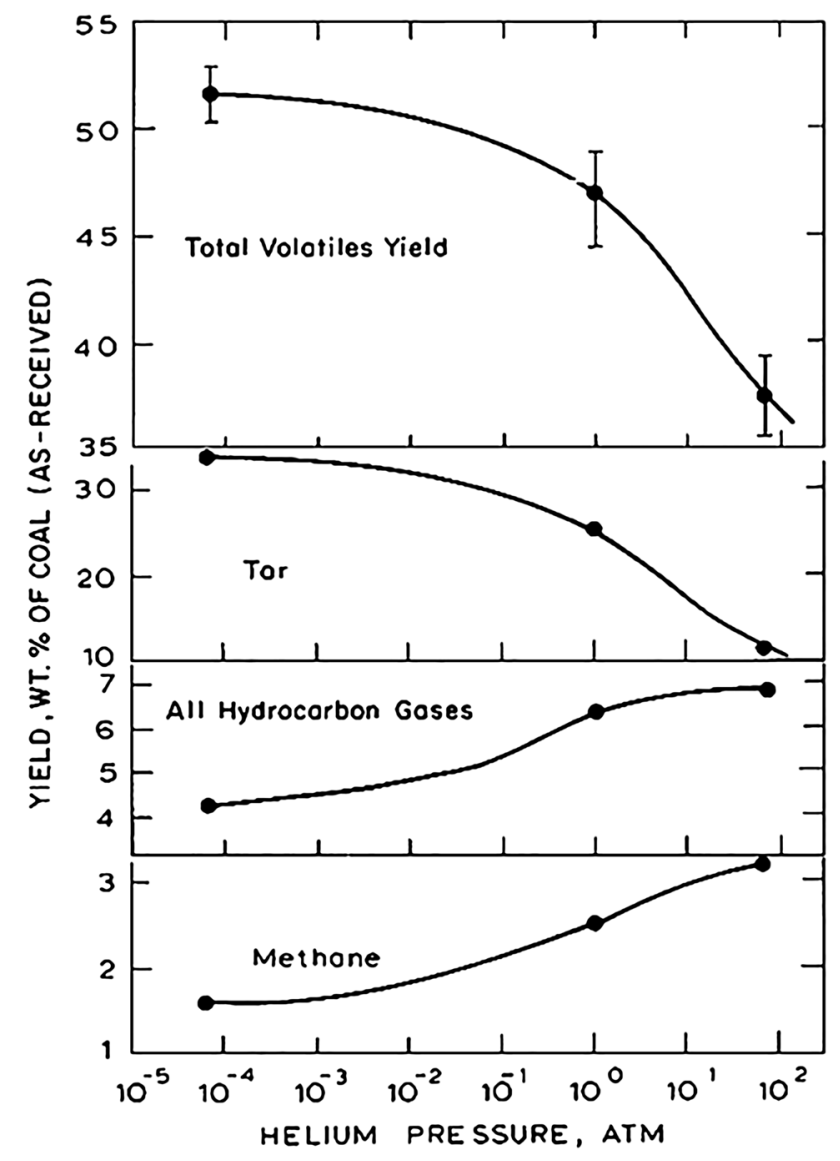

Fig. 7 The yields of volatile species vs. pressure during the pyrolysis of Pittsburgh No. 8 coal at 1270 K, Yu et al. (2007)

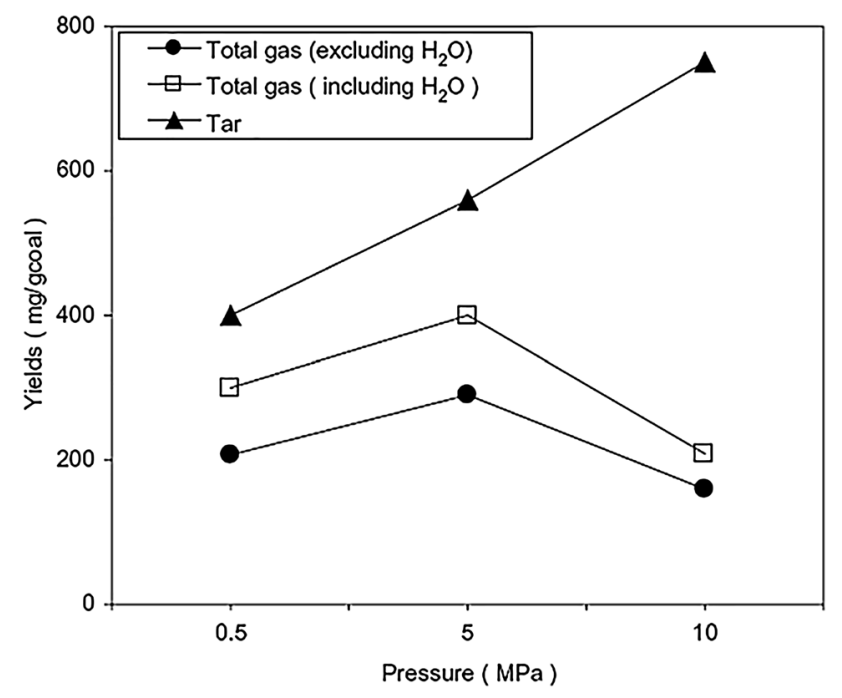

Fig. 8 Product yields versus pressure, Canel et al. (2005) 


\section{Conclusion}

This review has provided an overview of coal-char-gasification process. Coal gasification emerges to be an excellent green technology which along with securing energy demands will keep global warming in check. The coalchar-gasification process is affected by number of parameters. From the above study following conclusions are drawn in order to identify the effect of different operating parameters on coal gasification:

(1) Carbon conversion is a function of reaction time and it increases with increase in reaction time irrespective of different operating atmosphere.

(2) Carbon conversion and gasification rate increases with increase in gasification temperature.

(3) Pressure during pyrolysis affects the gasification reactivity of char but still no general trend has been found which establishes a relation between pyrolysis pressure and gasification reactivity.

(4) Lower rank coals are highly reactive than higher rank coals due to high concentration of active sites in a coal matrix of lower rank coal.

(5) Pore structure of char is a factor which controls the gasification reaction rate although it is not a controlling factor for highly reactive chars.

(6) Reactivity of char is a function of catalyst percentage i.e., reactivity increases with increasing catalyst percentage up to a certain limit beyond that it not considerable. Rank of coal also considerably affects the catalytic reactivity.

Open Access This article is distributed under the terms of the Creative Commons Attribution 4.0 International License (http://crea tivecommons.org/licenses/by/4.0/), which permits unrestricted use, distribution, and reproduction in any medium, provided you give appropriate credit to the original author(s) and the source, provide a link to the Creative Commons license, and indicate if changes were made.

\section{References}

Agarwal AK, Sears JT (1980) The coal char reaction with $\mathrm{CO}_{2}-\mathrm{CO}$ gas mixtures. Ind Eng Chem Process Des Dev 79:364-371

Ahn DH, Gibbs BM, Ko KH, Kim JJ (2001) Gasification kinetics of an indonesian sub-bituminous coal-char with $\mathrm{CO} 2$ at elevated pressure. Fuel 80:1651-1658

Alvarez T, Fuertes AB, Pis JJ, Ehrburger P (1994) Influence of coal oxidation upon char gasification reactivity. Fuel 74(5):729-735

Basu P (2006) Combustion and gasification in fluidized beds. Taylor \& Francis Group, Abingdon-on-Thames

Beamish BB, Shaw KJ, Rodgers KA, Newman J (1998) Thermogravimetric determination of the carbon dioxide reactivity of char from some New Zealand coals and its association with the inorganic geochemistry of the parent coal. Fuel Process Technol $53: 243-253$
Bhatia SK, Gupta JS (1994) Mathematical modeling of gas-solid reactions: effect of pore structure. Rev Chem Eng $8(3-4): 177-258$

Cakal GO, Yucel H, Guruzm AG (2007) Physical and chemical properties of selected Turkish lignites and their pyrolysis and gasification rates determined by thermogravimetric analysis. J Anal Appl Pyrolysis 80:262-268

Canel M, Misirloglu Z, Sinag A (2005) Hydropyrolysis of a Turkish lignite (Tuncbilek) and effect of temperature and pressure on product distribution. Energy Convers Manag 46:2185-2197

Corella J, Toledo JM, Molina G (2006) Steam gasification of coal at low-medium $\left(600-800{ }^{\circ} \mathrm{C}\right)$ temperature with simultaneous $\mathrm{CO} 2$ capture in fluidized bed at atmospheric pressure: the effect of inorganic species. 1. Literature review and comments. Ind Eng Chem Res 45:6137-6146

Everson RC, Neomagus HWJP, Kaitano R, Falcon R, Cann VMD (2008) Properties of high ash coal-char particles derived from inertinite-rich coal: II. Gasification kinetics with carbon dioxide. Fuel 87:3403-3408

Feng B, Bhatia SK (2003) Variation of the pore structure of coal chars during gasification. Carbon 41:507-523

Fouga GG, Micco GD, Bohe A (2011) Kinetic study of Argentinean asphaltite gasification using carbon dioxide as gasifying agent. Fuel 90:674-680

Harris DJ, Roberts DG, Henderson DG (2006) Gasification behaviour of Australian coals at high temperature and pressure. Fuel 85:134-142

Hattingh BB, Everson RC, Neomagus HWJP, Bunt JR (2011) Assessing the catalytic effect of coal ash constituents on the $\mathrm{CO}_{2}$ gasification rate of high ash, South African coal. Fuel Process Technol 92:2048-2054

Hirsch PB (1954) X-ray scattering from coals. Proc R Soc A Lond 226:143-169

Hoffmann BS, Szklo A (2011) Integrated gasification combined cycle and carbon capture: a risky option to mitigate $\mathrm{CO} 2$ emissions of coal-fired power plants. Appl Energy 88:3917-3929

Hurt RH, Sarofim AF, Longwell JP (1991) The role of microporous surface area in the gasification of chars from a sub-bituminous coal. Fuel 70:1079-1082

IPCC (2014) Climate change 2014: mitigation of climate change. In: Edenhofer $\mathrm{O}$ et al (eds) Contribution of working group III to the fifth assessment report of the intergovernmental panel on climate change. Cambridge University Press, Cambridge

Jenkins RG, Nandi SP, Walker PL Jr (1973) Reactivity of heat-treated coals in air at $500{ }^{\circ} \mathrm{C}$. Fuel 52:288-293

Kiihl H, Kashani-Motlagh MM, Miihlen H-J, Van Heek KH (1992) Controlled gasification of different carbon materials and development of pore structure. Fuel 71:879-882

Kim YT, Seo DK, Hwang J (2011) Study of the effect of coal type and particle size on char $\mathrm{CO}_{2}$ gasification via gas analysis. Energy Fuels 25:5044-5054

Kristiansen A (1996) Understanding coal gasification. IEA Coal Research, London

Li C-Z (2007) Some recent advances in the understanding of the pyrolysis and gasification behaviour of Victorian brown coal. Fuel 86:1664-1683

Liu G, Benyon P, Benfella KE, Bryanta GW, Tatea AG, Boyd RK, Harrisc DJ, Walla TF (2000) The porous structure of bituminous coal chars and its influence on combustion and gasification under chemically controlled conditions. Fuel 79:617-626

Liu TF, Fang YT, Wang Y (2008) An experimental investigation into the gasification reactivity of chars prepared at high temperatures. Fuel 87:460-466

Mahinpey N, Gomez A (2016) Review of gasification fundamentals and new findings: reactors, feed stock and kinetic studies. Chem Eng Sci 148:14-31 
Messenbock RC, Paterson NP, Dugwell DR, Kandiyoti R (2000) Factors governing reactivity in low temperature coal gasification. Part 1. An attempt to correlate results from a suite of coals with experiments on maceral concentrates. Fuel 79:109-121

Miura K, Hashimotot K, Silveston PL (1989) Factors affecting the reactivity of coal chars during gasification and indices representing reactivity. Fuel 68:1461-1475

NCC (2015) Fossil forward: revitalizing CCS bringing scale and speed to CCS deployment. National Coal Council, Washington

Ochoa J, Cassanello MC, Bonelli PR, Cukierman AL (2001) CO gasification of Argentinean coal chars a kinetic characterization. Fuel Process Technol 74:161-176

Radovic LR, Walker PL Jr, Jenkins RG (1983) Carbon active sites in coal char gasification fuel. Fuel 62:849-856

Roberts DG, Harris DJ, Wall TF (2003) On the effects of high pressure and heating rate during coal pyrolysis on char gasification reactivity. Energy Fuels 17:887-895

Rodrigues-Reinoso F (1991) Controlled gasification of carbon and pore structure development. In: Lahaye J, Ehrburger P (eds) Fundamental issues in control of carbon gasification reactivity. Springer, Dordrecht, pp 533-571

Rubin ES, Davison JE, Herzog HJ (2015) The cost of CO2 capture and storage. Int J Greenhouse Gas Control 40:378-400

Saha S (2013) Studies on physical properties of Indian coals and its effect on coal gasification kinetics, (Ph.D Dissertation). Indian School of Mines, Dhanbad, India

Schobert HH (1992) Catalytic and chemical behaviour of coal mineral matter behaviour in the coal conversion process. In: Yürüm Y (ed) Clean utilization of coal: coal structure and reactivity, cleaning and environmental aspects. Kluwer Academic Publishers, Dordrecht, pp 65-73

Sha XZ, Chen YG, Cao J, Yang YM, Ran DQ (1990) Effects of operating pressure on coal gasification. Fuel 69:656-659
Shufen L, Ruizheng S (1994) Kinetic studies of a lignite char pressurized gasification with $\mathrm{CO}, \mathrm{H}_{2}$ and steam. Fuel 73(3):413-416

Siauw HN, Fung DPC, Kim SD (1984) Some physical properties of Canadian coals and their effects on coal reactivity. Fuel 63:1564-1569

Simons GA (1983) The role of pore structure in coal pyrolysis and gasification. Prog Energy Combust Sci 9:269-290

Song BH, Kim S (1993) Catalytic activity of alkali and iron salt mixtures for steam-char gasification. Fuel 72(6):797-803

Takarada T, Tamai Y, Tomita A (1986) Effectiveness of $\mathrm{K}_{2} \mathrm{CO}_{3}$ and $\mathrm{Ni}$ as catalysts in steam gasification. Fuel 65:679-683

Tanner J, Bhattacharya S (2016) Kinetics of CO2 and steam gasification of Victorian brown coal chars. Chem Eng J 285:331-340

Wang G, Zhang J, Hou X, Shao J (2015) Geng W, Study on CO2 gasification properties and kinetics of biomass chars and anthracite char. Biores Technol 177:66-73

Wu Y, Wu S, Gu J, Gao J (2009) Differences in physical properties and $\mathrm{CO}_{2}$ gasification reactivity between coal char and petroleum coke. Process Saf Environ Prot 87:323-330

Xiao R, Zhang M, Jin B, Huang Y (2006) High-temperature air/ steam-blown gasification of coal in a pressurized spout-fluid bed. Energy Fuels 20:715-720

Ye DP, Agnew JB, Zhang DK (1998) Gasification of a South Australian low-rank coal with carbon dioxide and steam: kinetics and reactivity studies. Fuel 77(11):1209-1219

Yu J, Lucas JA, Wall TF (2007) Formation of the structure of chars during devolatilization of pulverized coal and its thermoproperties: a review. Prog Energy Combust Sci 33:135-170

Zhang L, Huang J, Fang Y, Wang Y (2006) Gasification reactivity and kinetics of typical chinese anthracite chars with steam and $\mathrm{CO}_{2}$. Energy Fuels 20:1201-1210 